\title{
C-C Motif Chemokine 26
}

National Cancer Institute

\section{Source}

National Cancer Institute. C-C Motif Chemokine 26. NCI Thesaurus. Code C28739.

C-C motif chemokine 26 (94 aa, $11 \mathrm{kDa}$ ) is encoded by the human CCL26 gene. This protein plays a role in eosinophil and basophil chemotaxis. 